\title{
AN ADVERSE EFFECT OF THE VENTRAL PROSTATE SECRETION ON HAMSTER EPIDIDYMAL SPERMATOZOA
}

\author{
Z. MORITA* AND M. G. GHANG \\ Worcester Foundation for Experimental Biology, \\ Shrewsbury, Massachusetts 01545, U.S.A.
}

(Received 20th April 1970)

\begin{abstract}
Summary. The motility and metabolism of hamster epididymal spermatozoa in the presence of secretions from the ventral prostate gland have been studied. The aerobic metabolism and motility of hamster epididymal spermatozoa were depressed by a factor of large molecular size which could be partially but not completely destroyed by heating, even at $90^{\circ} \mathrm{C}$ for $10 \mathrm{~min}$. Treatment of the ventral prostate secretion with EDTA had no effect on this factor, indicating that its activity is not dependent on divalent cations. The presence of 0.01 to $0.1 \%$ cysteine had no visible effect on the activity of this factor, suggesting that sulphydryl binding is also not involved. Its adverse effect on spermatozoa could not be neutralized by the secretion of other accessory glands. Hamster epididymal spermatozoa were more sensitive to the hamster ventral prostate secretion than mouse and rat epididymal spermatozoa and the ventral prostate secretions of the mouse and rat appeared to have no adverse effect on their epididymal spermatozoa.
\end{abstract}

\section{INTRODUGTION}

Although a great deal of information is now available concerning the metabolism and motility of ejaculated spermatozoa (Bishop, 1961, 1962; Mann, 1964, 1967; Nelson, 1967), little is known of the effects of the secretions of accessory glands on the metabolism and motility of epididymal spermatozoa. There is some evidence, however, that an adverse factor in bovine seminal plasma, probably a protein, depresses the viability of bull spermatozoa (Shannon, 1965). This factor appears to be present in the secretions of the seminal vesicles (Bennett \& Dott, 1967).

In the course of investigations into the motility and metabolism of spermatozoa in rodents, it was found that the metabolic activity of hamster epididymal spermatozoa was severely depressed in the presence of secretions from the ventral prostate of the hamster (Morita \& Chang, 1971a, b). It is the purpose of this study to examine the characteristics of the adverse factor secreted by the ventral prostate gland of the hamster and to discuss its biological nature.

* Present address: Faculty of Agriculture, Tottori University, Tottori, Japan. 
Sperm suspension and male accessory secretion

Spermatozoa (about $0.2 \mathrm{ml}$ ) were expressed from the cauda epididymidis of a hamster, rat or mouse and then mixed with $2 \mathrm{ml}$ of Hanks' solution containing penicillin $(50 \mu \mathrm{g} / \mathrm{ml})$ and glucose $(1 \mathrm{mg} / \mathrm{ml})$. After killing a mature hamster, the fresh ventral prostate gland (Price \& Williams-Ashman, 1961) was isolated and placed in a watch glass. About $0.02 \mathrm{ml}$ of its secretion was suspended in $1.0 \mathrm{ml}$ of Hanks' solution for various tests.

\section{Motility}

One drop of sperm suspension (about $0.04 \mathrm{ml}$ ) was mixed with five drops of diluted secretion (about $0.2 \mathrm{ml}$ ) of the ventral prostate in a watch glass and the preparation was covered with mineral oil and incubated at $37^{\circ} \mathrm{C}$. The final concentration of spermatozoa in the mixture was 0.2 to $0.4 \times 10^{8} / \mathrm{ml}$. The motility of spermatozoa in the watch glass was examined under a compound microscope $(10 \times 20)$ placed in a warm chamber (at about $33^{\circ} \mathrm{G}$ ) $1 \mathrm{hr}$ after preparation and then examined every $2 \mathrm{hr}$ for $24 \mathrm{hr}$. The grade of motility was recorded according to the system of Emmens (1947) and the ranges of motility duration (in hours) of three replications for each test were recorded. Recordings were made of the duration in hours that the initial progressive motility was maintained and the length of time to the complete cessation of motility.

\section{Metabolic experiments}

For manometric measurements, $0.3 \mathrm{ml}$ sperm suspension was mixed with $0.7 \mathrm{ml} \mathrm{Ga-free} \mathrm{Krebs-Ringer-phosphate} \mathrm{solution} \mathrm{(with} \mathrm{a} \mathrm{fructose} \mathrm{con-}$ centration of $3 \mathrm{mg} / \mathrm{ml}$ ) or mixed with diluted secretions of the ventral prostate in Ca-free Krebs-Ringer-phosphate solution. The final concentration of spermatozoa in a Warburg flask was 0.5 to $1.0 \times 10^{8}$. The sperm suspension $(1.0 \mathrm{ml})$ was incubated at $37^{\circ} \mathrm{C}$ in Warburg flasks containing $20 \% \mathrm{KOH}$ in the centre well. Oxygen uptake was measured for $2 \mathrm{hr}$ with air as the gas phase and a shaking rate of 120 strokes $/ \mathrm{min}$. Sperm counts were made with a haemocytometer after the completion of manometry. Fructose concentration was estimated by the method of Mann (1948) at the start and at the end of manometry.

\section{Decrease of the aerobic metabolic activity of spermatozoa}

The results of metabolic determinations of hamster spermatozoa in the presence or absence of the secretion from the ventral prostate of the hamster are given in Table 1.

The oxygen uptake was maintained at a relatively steady rate in the spermatozoa suspended in Krebs-Ringer-phosphate solution during the 2-hr period of incubation. By contrast, the respiration of spermatozoa suspended in the diluted secretion of the hamster ventral prostate dropped sharply during the second hour of incubation. Fructose utilization by $10^{9}$ spermatozoa/hr was also low in spermatozoa suspended in the diluted secretion from the ventral prostate as compared to that of spermatozoa suspended in Krebs-Ringer-phosphate (Table 1). 
Physico-chemical properties of the inhibitory factor

Table 2 presents the results of experiments on the motility of hamster spermatozoa suspended in Hanks' solution (containing calcium chloride) without the secretion of the hamster ventral prostate and also with the secretion treated in various ways.

\section{TABLE 1}

AEROBIC METABOLISM OF HAMSTER SPERMATOZOA SUSPENDED IN KREBSRINGER-PHOSPHATE WITH OR WITHOUT THE SECRETION OF THE HAMSTER VENTRAL PROSTATE GLAND

\begin{tabular}{c|cc|c}
\hline \multicolumn{1}{c|}{ Medium } & \multicolumn{2}{|c|}{$\begin{array}{c}\text { Oxygen uptake } \\
\left(\mu \mathrm{l} / 10^{8} \text { sperm./hr }\right)\end{array}$} & $\begin{array}{c}\text { Fructose } \\
\text { utilized } \\
\left(\mathrm{mg} / 10^{9}\right. \\
\text { sperm./hr })\end{array}$ \\
\hline $\begin{array}{l}\text { Krebs-Ringer-phosphate } \\
\begin{array}{l}\text { Krebs-Ringer-phosphate } \\
\text { with secretion }\end{array}\end{array}$ & $18 \cdot 13 \pm 1.08$ & $31.37 \pm 1.88$ & $1.48 \pm 0.089$ \\
\hline
\end{tabular}

Mean values \pm S.E. of four replications are given in the table.

$* P<0.05$ as compared with Krebs-Ringer-phosphate without ventral prostate secretion.

\section{TABLE 2}

EFFECT OF VARIOUS TREATMENTS OF THE SECRETIONS FROM THE VENTRAL PROSTATE ON THE MOTILITY OF HAMSTER SPERMATOZOA AT $37^{\circ} \mathrm{C}$

\begin{tabular}{|c|c|c|c|}
\hline \multirow{2}{*}{\multicolumn{2}{|c|}{ Secretion of ventral prostate }} & \multicolumn{2}{|c|}{$\begin{array}{l}\text { Duration of motility } \\
\text { of spermatozoa }(\mathrm{hr})\end{array}$} \\
\hline & & $A$ & $B$ \\
\hline (1) & Control, Hanks' solution without secretion & 10 to 12 & 12 to 24 \\
\hline (2) 1 & Fresh, untreated secretion & 0 to $\frac{1}{2}$ & 0 to $\frac{1}{2}$ \\
\hline (3) 1 & $\begin{array}{r}\text { Heated for } 30 \mathrm{~min} \text { at } 56^{\circ} \mathrm{C} \\
15 \mathrm{~min} \text { at } 75^{\circ} \mathrm{C} \\
10 \mathrm{~min} \text { at } 90^{\circ} \mathrm{C}\end{array}$ & $\begin{array}{l}1 \text { to } 2 \\
1 \text { to } 2 \\
2 \text { to } 4\end{array}$ & $\begin{array}{l}2 \text { to } 4 \\
4 \text { to } 6 \\
6 \text { to } 8\end{array}$ \\
\hline (4) 1 & $\begin{array}{l}\text { Permeability through collodion filter } \\
\text { Dialysable portion of the secretion } \\
\text { Non-dialysable portion of the secretion }\end{array}$ & $\begin{array}{l}6 \text { to } 8 \\
0 \text { to } \frac{1}{2}\end{array}$ & $\begin{array}{c}12 \text { to } 24 \\
0 \text { to } \frac{1}{2}\end{array}$ \\
\hline (5) 1 & $\begin{array}{r}\text { Fresh secretion }+\mathrm{m} / 100 \text { EDTA } \\
+\mathrm{m} / 200 \text { EDTA } \\
+\mathrm{m} / 500 \text { EDTA }\end{array}$ & $\begin{array}{l}0 \text { to } \frac{1}{2} \\
0 \text { to } \frac{1}{2} \\
0 \text { to } \frac{1}{2}\end{array}$ & $\begin{array}{l}0 \text { to } \frac{1}{2} \\
\frac{1}{2} \text { to } 1 \\
\frac{1}{2} \text { to } 1\end{array}$ \\
\hline (6) & $\begin{aligned} \text { Fresh secretion } & +0.1 \% \text { cysteine } \mathrm{HCl} \\
& +0.05 \% \text { cysteine } \mathrm{HCl} \\
& +0.1 \% \text { cysteine } \mathrm{HCl}\end{aligned}$ & $\begin{array}{l}0 \text { to } \frac{1}{2} \\
0 \text { to } \frac{1}{2} \\
0 \text { to } \frac{1}{2}\end{array}$ & $\begin{array}{l}\frac{1}{2} \text { to } 1 \\
\frac{1}{2} \text { to } 1 \\
\frac{1}{2} \text { to } 1\end{array}$ \\
\hline
\end{tabular}

EDTA: Ethylene diamine tetra-acetate.

A: Incubation period for the maintenance of the initial progressive motility.

B: Incubation period when no motility was observed.

Spermatozoa became completely immotile in a short period (within $30 \mathrm{~min}$ ) after being mixed with fresh secretion from the ventral prostate of the hamster, while the motility of spermatozoa was well maintained for an extended period 
(10 to $12 \mathrm{hr}$ ) in Hanks' solution at $37^{\circ} \mathrm{C}$. The factor which inhibited sperm motility was partly destroyed by heating the secretion at $56^{\circ} \mathrm{C}$ for $30 \mathrm{~min}$ or at $75^{\circ} \mathrm{G}$ for $15 \mathrm{~min}$, though it could not be completely destroyed even by heating at $90^{\circ} \mathrm{C}$ for $10 \mathrm{~min}$. It could not pass through a collodion bag filter, estimated to retain proteins with a molecular weight of approximately 70,000 to 100,000 . The addition of ethylene diamine tetra-acetate (EDTA) to the diluted secretion of ventral prostate had no effect on its activity. This indicates that the factor is active even when some cations, such as $\mathrm{Mg}^{++}, \mathrm{Ca}^{++}$or $\mathrm{Fe}^{++}$, are absent.

Since the addition of cysteine $\mathrm{HCl}$ to the diluted secretion also had no effect on the activity of this factor, its adverse effect is presumably not due to any sulphydryl-binding capacity.

Species differences in sensitivity to this factor

Fresh hamster, rat and mouse epididymal spermatozoa were suspended in various dilutions (1:0 to $1: 64)$ of the secretion of the ventral prostate of the

\section{TABLE 3}

EFFECT OF DILUTED SEGRETION OF THE HAMSTER VENTRAL PROSTATE ON THE DURATION OF THE MOTILITY OF EPIDIDYMAL SPERMATOZOA OF THE HAMSTER, THE RAT AND THE MOUSE AT $37^{\circ} \mathrm{G}$

\begin{tabular}{|c|c|c|c|c|c|c|}
\hline \multirow{3}{*}{$\begin{array}{c}\text { Dilution rate } \\
\text { with } \\
\text { Hanks' solution }\end{array}$} & \multicolumn{6}{|c|}{ Duration of motility of epididymal spermatozoa $(h r)$} \\
\hline & \multicolumn{2}{|c|}{ Hamster } & \multicolumn{2}{|c|}{ Rat } & \multicolumn{2}{|c|}{ Mouse } \\
\hline & $A$ & $B$ & $A$ & $B$ & $A$ & $B$ \\
\hline $\begin{array}{r}0 \\
2 \\
4 \\
8 \\
16 \\
32 \\
64 \\
\text { Hanks' solution }\end{array}$ & $\begin{array}{l}0 \text { to } \frac{1}{2} \\
0 \text { to } \frac{1}{2} \\
0 \text { to } \frac{1}{2} \\
0 \text { to } \frac{1}{2} \\
1 \text { to } 2 \\
4 \text { to } 6 \\
10 \text { to } 12 \\
10 \text { to } 12\end{array}$ & $\begin{array}{c}0 \text { to } \frac{1}{2} \\
\frac{1}{2} \text { to } 1 \\
1 \text { to } 2 \\
4 \text { to } 6 \\
8 \text { to } 12 \\
10 \text { to } 12 \\
10 \text { to } 24 \\
12 \text { to } 24\end{array}$ & $\begin{array}{l}4 \text { to } 6 \\
4 \text { to } 6 \\
4 \text { to } 6 \\
4 \text { to } 6 \\
4 \text { to } 6 \\
6 \text { to } 8 \\
6 \text { to } 8 \\
6 \text { to } 8\end{array}$ & $\begin{array}{c}4 \text { to } 6 \\
4 \text { to } 6 \\
6 \text { to } 8 \\
6 \text { to } 8 \\
10 \text { to } 12 \\
10 \text { to } 12 \\
10 \text { to } 12 \\
10 \text { to } 12\end{array}$ & $\begin{array}{l}2 \text { to } 4 \\
2 \text { to } 4 \\
2 \text { to } 4 \\
2 \text { to } 4 \\
4 \text { to } 6 \\
4 \text { to } 6 \\
4 \text { to } 6 \\
4 \text { to } 6\end{array}$ & $\begin{array}{l}2 \text { to } 4 \\
2 \text { to } 4 \\
4 \text { to } 6 \\
6 \text { to } 8 \\
6 \text { to } 8 \\
6 \text { to } 8 \\
6 \text { to } 8 \\
6 \text { to } 10\end{array}$ \\
\hline
\end{tabular}

A: Incubation period for the maintenance of the initial progressive motility. B: Incubation period when no motility was observed.

hamster mixed with Hanks' solution. The results are presented in Table 3. The secretion was relatively ineffective against mouse spermatozoa ( 2 to $4 \mathrm{hr}$ ) and rat spermatozoa ( 4 to $6 \mathrm{hr}$ ). The dilution rate of the secretion which appeared to have an adverse effect was $1: 32$ for hamster spermatozoa, 1:8 for mouse spermatozoa and 1:16 for rat spermatozoa, indicating a species difference in the sensitivity of epididymal spermatozoa to the secretion.

The adverse effect of the secretion from the ventral prostate seemed to be specific to the hamster as no such effect was observed in the secretions of the rat and mouse ventral prostate on rat and mouse epididymal spermatozoa.

Failure to neutralize the adverse effect by the secretions from other accessory glands

To $0.1 \mathrm{ml}$ of diluted secretions from the ventral prostate of the hamster, $0 \cdot 1 \mathrm{ml}$ of diluted secretion from the seminal vesicles, coagulating gland or dorsal prostate of the hamster was added separately. One drop of epididymal sperm 
suspension $(0.04 \mathrm{ml})$ from the hamster was then mixed with $0.2 \mathrm{ml}$ of these diluted secretions. All spermatozoa were immobilized in each mixture within $30 \mathrm{~min}$. This indicates that the factor in the secretion of ventral prostate cannot be neutralized by the secretions of the other hamster male accessory glands.

\section{DISGUSSION}

The seminal plasma contributed by the accessory glands can conceivably serve as vehicle for sperm transport, as a medium containing essential inorganic ions of adequate buffering capacity, as an optimal osmotic milieu, and as a source of energy substrates (Bishop, 1961). The beneficial effect of large molecular substances in seminal plasma for the maintenance of the fertilizing capacity of rabbit spermatozoa was demonstrated by Chang (1947).

On the other hand, some components of seminal plasma may be by-products with no obvious beneficial rôle and may even have harmful effects on the gametes. A factor (probably a protein) present in bovine seminal plasma, which depresses the viability of spermatozoa, also appears to have a direct action on the spermatozoa and its effect is not due to the degradation of the seminal plasma (Shannon, 1965). Bovine seminal plasma has been reported to depress the impedance change frequency of epididymal spermatozoa (Bennett \& Dott, 1967). In the rat, however, the motility of epididymal spermatozoa can be maintained by the addition of supernatant obtained from the secretion of the seminal vesicles mixed with a few drops of the secretion from the coagulating gland but not by the addition of fresh secretion from the seminal vesicles alone (Morita \& Ghang, 1971a). The oxygen consumption of spermatozoa is depressed in the presence of vaginal, cervical and uterine secretions but is markedly stimulated in the presence of fluid from the oviducts and follicles (Olds \& VanDemark, 1957). Murdoch \& White (1968) found that when uterine fluid was present in sperm storage medium containing glucose, subsequent glycolytic activity, but not oxygen uptake, was depressed. At present, little is known of the properties of inhibitory factor(s) in the secretions of the female genital tract.

In the rat, the ventral prostate gland is known to contain several phosphatases and a remarkably high concentration of citric acid, but is without fructose (Humphrey \& Mann, 1948, 1949). The presence of citric acid in hamster ventral prostate secretion might depress the motility of hamster spermatozoa due to its binding capacity with calcium ions which are necessary for the maintenance of hamster sperm motility (Morita \& Chang, 1971b). Citric acid cannot, however, be the determining factor because of its resistance to heat and its ability to pass through a collodion bag filter (Table 2).

\section{ACKNOWLEDGMENTS}

This work was supported by a grant (HD 03003) from the National Institute of Ghild Health and Human Development, United States Public Health Service; and a grant from the Ford Foundation. 


\section{REFERENCES}

BENNETT, J. P. \& Dotr, H. M. (1967) Effect of seminal plasma on epididymal spermatozoa in the bull. Int. F. Fert. 12, 21.

Brshop, D. W. (1961) Biology of spermatozoa. In: Sex and Internal Secretions, Vol. II, pp. 707-796. Ed. W. G. Young. Williams \& Wilkins, Baltimore.

Brssop, D. W. (1962) Sperm motility. Physiol. Rev. 42, 1.

Ghang, M. C. (1947) Effects of testis hyaluronidase and seminal fluids on the fertilizing capacity of rabbit spermatozoa. Proc. Soc. exp. Biol. Med. 66, 51.

Emmens, G. W. (1947) The motility and viability of rabbit spermatozoa at different hydrogen-ion concentrations. F. Physiol., Lond. 106, 471.

Humphrey, G. F. \& ManN, T. (1948) Gitric acid in semen. Nature, Lond. 161, 352.

Humphrey, G. F. \& ManN, T. (1949) Studies on the metabolism of semen. 5. Citric acid in semen. Biochem. 7. 44, 97.

ManN, T. (1948) Fructose content and fructolysis in semen. Practical application in the evaluation of semen quality. 7. agric. Sci., Camb. 38, 323.

MANN, T. (1964) The biochemistry of semen and of the male reproductive tract. Methuen, London.

MANN, T. (1967) Sperm metabolism. In: Fertilization, Vol. I, pp. 99-116. Eds. C. B. Metz and A. Monroy. Academic Press, New York.

Morita, Z. \& Chang, M. C. (1971a) Maintenance of the motility of rat epididymal spermatozoa in the presence of male accessory secretions. 7. Reprod. Fert. 24, 247.

Morita, Z. \& Chang, M. G. (1971b) The motility and aerobic metabolism of spermatozoa in laboratory animals with special reference to the effects of cold shock and the importance of calcium for the motility of hamster spermatozoa. Biol. Reprod. (In press).

Murdoch, R. N. \& White, I. G. (1968) Metabolic studies on testicular, epididymal, and ejaculated spermatozoa of the ram. Aust. F. biol. Sci. 21, 111.

NeLson, L. (1967) Sperm motility. In: Fertilization, Vol. I, pp. 27-97. Eds G. B. Metz and A. Monroy. Academic Press, New York.

Olds, D. \& VANDENMARK, N. L. (1957) The behavior of spermatozoa in luminal fluids of bovine female genitalia. Am. F. vet. Res. 18, 603 .

Price, D. \& Williams-Ashman, H. G. (1961) The accessory reproductive glands of mammals. In: Sex and Internal Secretions, Vol. I, 3rd edn, Chapter 6, pp. 366-448. Williams \& Wilkins, Baltimore.

Shannon, P. C. (1965) Presence of a heat-labile toxic protein in bovine seminal plasma. F. Dairy Sci. 48, 1362. 